FROM THE EDITOR

\title{
Who needs the concept of spirituality? Human beings seem to!
}

Well, it's finally happened. I've been attacked in the scientific literature (Salander, 2006). Well, just to clarify, it wasn't a personal attack, but rather an attack of the highest and most noble order: an attack on the scientific rigor of the conceptual underpinnings of my recent work on meaning and spirituality in advanced cancer patients (e.g., Breitbart, 2002). To be honest, and a bit less grandiose, it was not an attack against me alone, but rather a set of critical comments aimed at a growing number of investigators who have been publishing papers (a $600 \%$ increase over the past 10 years) dealing with religious or spiritual aspects of life-threatening illness (Stefanek et al., 2005). The critical comments by Dr. Par Salander of the Department of Social Welfare, Umea University, Sweden, in a recent issue of the journal Psycho-oncology (Salander, 2006) challenge the need for and the validity of the concept of spirituality.

Professor Salander is a thoughtful researcher who has published broadly in the area of psychooncology, including a recent article in our own Palliative \& Supportive Care (a journal devoted to the psychiatric, psychosocial, existential, and "spiritual" domains of palliative and supportive care). $\mathrm{He}$ is also clearly versed in aspects of existential philosophy and psychotherapy (e.g., Frankl, 1959; Yalom, 1980). The main challenges of his question, "Who needs the concept of spirituality?" fall into several categories: (1) Spirituality as a "concept" is poorly defined or operationalized; (2) the concept of spirituality is not linked to any theory and lacks a systemic meaning; (3) the term spiritual is unnecessarily and inaccurately being used to describe what are essentially existential issues, and; (4) finally, the universality of the term spiritual is challenged, pointing out that it may be acceptable and reasonable to ask an American if he or she is a "spiritual person," but that such a question would be quite irrelevant and alien to a Swede or a "nonEnglish speaking secular European." Professor Salander correctly points out examples of papers where the term spiritual is used inconsistently: some pa- pers in which it is alternately used to describe religious beliefs or religiosity, papers in which the term is used to describe existential concepts of meaning and purpose, and finally papers in which the concept is used to refer to general psychosocial issues (Breitbart, 2002; Meraviglia, 2004; Murray et al., 2004; Krupski et al., 2006). Dr. Salander asks us to use the terms religion or religious, rather than spiritual, when we mean religious and to use the terms meaning, purpose, or existential, rather than spiritual, when we mean meaning and so on.

Clearly, there is a need for clarity in our definitions of concepts such as spirituality as well as a need for accuracy and specificity in this realm of research. But Professor Salander has gone one step beyond challenging researchers in the area of "spirituality or spiritual well-being" to be more accurate and specific in the description of these concepts and what they are in fact measuring in their studies. He is directly challenging the need for the concept of spirituality independent of the terms religious and existential and proposes that spirituality as a concept is irrelevant for the majority of the "secular" world (in particular secularized Europeans). In his critique of spirituality as a concept, Dr. Salander links the spiritual to the religious, and further links existential to the term secular. He even postulates that "the advocates of a religious/spiritual discourse substitute 'spiritual' for 'existential' because they dislike the latter's connection to existential philosophy and its denial of a God" (Salander, 2006, p. 648).

I would take exception with the above conceptualizations, particularly the notions that the term spiritual is only linked to religious and not secular worldviews and that existential is always linked to secular perspectives rather than religious perspectives.

Clearly there are multiple examples of "existential philosophers" who were quite religious in rather traditional senses (e.g., Kierkegaard and C.S. Lewis), existentialists who were theologians but stretched 
the concepts of God and God's existence (e.g., Tillich), existentialists who were atheists or at least agnostics (e.g., Sartre and Heidegger), and secularists/ scientists who believe in a "spiritual dimension of human experience" and an alternative concept of God that does not fit traditional religious views of God (e.g., Einstein and Sagan). I find the writings of Albert Einstein and Carl Sagan particularly helpful in conceptualizing what is spiritual about the human condition in a manner that is independent of traditional religion and is distinct perhaps from atheistic existentialism, a concept that I believe is universal in the human experience, particularly when one faces one's mortality, and is worth "measuring" as an element of the illness/cancer experience.

I will focus on Carl Sagan's writing here (Sagan, 2006), because I have just recently finished reading a posthumously published collection of lectures, the famous Gifford Lectures on Natural Theology, given by him in 1985 in Scotland. Previous Gifford Lecturers have included Paul Tillich, Niels Bohr, Albert Scweitzer, and Hannah Arendt. Carl's widow and longtime scientific collaborator, Ann Druyan, has edited and compiled the nine Gifford Lectures delivered by Sagan into a remarkable volume entitled The Varieties of Scientific Experience: A Personal View of the Search for God (Sagan, 2006). Sagan, like Spinoza and Einstein, had a scientist's/ secularists view of God. He did not believe in a Biblical God, but rather defined God as "something not very different from the sum total of the physical laws of the universe: gravity, plus quantum mechanics, plus the unified field theories, plus a few other things (perhaps string theory) equaled 'God'" (Sagan, 2006, p. 149). Such a conceptualization of God unifies the scientists, secularists, and those of us who claim to be "spiritual" but not religious in the traditional sense. This concept of God provides a language for discussing not only existential issues, but spiritual issues. Existential issues deal with the examination of our existence. Acknowledging that we are grounded in the human condition and yearn to seek what lies beyond our limitations is where the existential and the spiritual perhaps meet. Sagan suggests that what is quintessentially a "spiritual" pursuit of human beings is "the search each human being undertakes to find a sense of peace in one's relationship to the universe" (Sagan, 2006 , p. 150). This human pursuit is universal, related to but distinct from Frankl's concept of a search for meaning, and is perhaps at its most intense when we as human beings are confronting our mortality in the context of a life-threatening illness like cancer.

So, spirituality is a legitimate concept to measure in cancer illness and palliative care settings. Who needs the concept of spirituality? I believe we "Human Beings" do.

\section{REFERENCES}

Breitbart, W. (2002). Spirituality and meaning in supportive care: Spirituality and meaning-centered group psychotherapy interventions in advanced cancer. Supportive Care in Cancer, 10, 272-280.

Frankl, V. (1959/1992). Man's Search for Meaning. Boston: Beacon Press.

Krupski, T.L., Kwan, L., Fink, A., et al. (2006). Spirituality influences health related quality of life in men with prostate cancer. Psycho-Oncology, 15, 132-142.

Meraviglia, M.G. (2004). The effect of spirituality on well-being of people with lung cancer. Oncology Nursing Forum, 31, 89-94.

Murray, S.A., Kendall, M., Boyd, K., et al. (2004). Exploring the spiritual needs of people dying of lung cancer or heart failure: A prospective qualitative interview study of patients and their carers. Palliative Medicine, 18, 39-45.

Sagan, C. (2006). The God hypothesis. In The Varieties of Scientific Experience: A Personal View of the Search for God, Druyan, A. (ed.), pp. 147-168. New York: Penguin Press.

Salander, P. (2006). Who needs the concept of "spirituality"? Psycho-Oncology, 15, 647-649.

Stefanek, M., McDonald, P.G., \& Hes, S.A. (2005). Religion, spirituality and cancer: Current status and methodological challenges. Psycho-Oncology, 14, 450-463.

Yalom, I. (1980). Existential Psychotherapy. New York: Basic Books.

WILLIAM BREITBART, M.D. Editor-in-Chief 